\title{
Habitat preferences and species diversity of anuran amphibians of Gaya India
}

Keywords: amphibian diversity, Gaya district, habitat preference, margalef richness index, polypedates maculatus, simpson diversity index

\section{Introduction}

The amphibian fauna of Bihar is very less studied as compared to the nearby states like West Bengal and Uttar Pradesh. It was also found that very less work has been conducted on the amphibian diversity of Bihar particularly Gaya. Any literature and publication is not available about the amphibian diversity of Gaya district. However the Gaya district is very rich in biodiversity. This district is land locked district its boarder meets with Jharkhand state in south and south eastern part. This area of Gaya district having high mountains with dense forest cover interspersed with patchy grassland and uneven patches of Bamboo grooves. The grassland and forest cover provides very suitable habitation for amphibian species. Rest of the areas of Gaya district is plain land utilizes for agricultural purpose as well for human habitation. The Gaya District with Barachatti and Dumaria dense forest showing high percent of rainfall, more humidity and low temperature as well the mixed scrub forest and deciduous forest. The plain land of Gaya district used for variety of crop pattern such as Paddy (Oryza sativa), Wheat (Triticum aestivum), Maize (Zea mays), Mung (Vigna radiata), Pigeon pea (Citer species) and sunflower (Helianthus annuus) provides the ideal environment and habitats for the amphibians. These variety of habitatas are the home to diverse group of amphibian species and also used for various purposes such as food and home ground etc. These sites of Gaya district are rich in herpatofauna (Amphibians and reptiles) co- inhibiting with wide range of biodiversity of different other species. ${ }^{1}$ Due to deforestation and changing in agricultural pattern of this area adversely affect the various fauna of this area but its impact on amphibian fauna is remaining unknown in the study area. There are 8,230 Amphibians species have been reported around the world, ${ }^{2}$ out of which 439 amphibian species (398 frogs, 2 salamanders and 39 caecilians) found in India. ${ }^{3}$ Recently Denesh et al., ${ }^{4}$ prepared a checklist of amphibian species found in India and described them, ${ }^{4}$ however there is very less description about the amphibian species of Bihar state.

First of all Venkateshwarulu et al., ${ }^{5}$ described the amphibian fauna of Bihar but that was very short description about the batrachians of this area. Later on Sarkar $\mathrm{AK}^{6}$ documented and give taxonomical account of 11 amphibians of Chhotanagpur Bihar. Sarkar et al., give taxonomical description of 14 species of amphibians from Bihar including Jharkhanad, but till today the diversity of amphibians of Gaya district remains unknown, hence attempt has been made to study the diversity of amphibians and their habitat preference of this area. Many workers and scientiests worked on the amphibian diversity and their habitat preference such as Abraham et al., ${ }^{8}$ Dahanukar et al., ${ }^{9}$, Krishnamurthy ${ }^{10}$ and Purushotham et al., ${ }^{11}$. Similar important works on amphibian were reported by Meren et al., ${ }^{12}$ and Ningombam et al., ${ }^{13}$ from the North-East India. These works have amply documented the diversity and microhabitats of amphibian species.

In the present study we surveyed in and around the areas of three different water bodies viz. Artificial pond (Ramsagar pond),
Volume 6 Issue 2 - 202।

\author{
Nalinaksh Pankaj,' Bhrigunath² \\ 'Ph.D Research Scholar, Department of Zoology, Magadh \\ University, Gaya \\ ${ }^{2}$ Associate Professor and Head Department of Zoology,AM \\ College Gaya
}

Correspondence: Nalinaksh Pankaj, University Department of Zoology, Magadh University Bodhgaya, Gaya, Tel 94380 I I 50, ORCID 0000-000I-8169-4830,

Email pankajnalinaksh@gmail.com

Received: December 24, 2020 | Published: March 16, 2021

Natural pond (Daboor village pond) and River (Falgu) of Gaya district selecting different microhabitats viz. Leaf litter and Bamboo grooves (LL\& BG), Tree hole (TH), Human residential area (HRA), Cultivated fields (CF), Patchy grasslands (PG), Forest and Hillly areas (FHA), Terrestrial Land (TL), and water bodies (WB). On the basis of extensive survey data gathered and prepared in the form of checklist of Amphibians of the Gaya district India. During the study some direct and indirect threats to the Amphibian diversity was also enlisted at the study area.

\section{Study area}

Gaya district is located between Latitude: 24.7969 Longitude: 85.9994 and is the main southern district of Bihar, India. The total area of this district is about $4,976 \mathrm{~km}^{2}$ and the elevation varies between $94 \mathrm{~m}$ to $104 \mathrm{~m}$. The area receives rainfall during Monsoon season. The average rainfall ranges between 1100-1300 mm. Average temperature of the district ranges from minimum of $4^{\circ} \mathrm{C}$ in winter to a maximum of $45^{\circ} \mathrm{C}$ in summer with the humidity ranges from $15-19 \%$ to $62-98 \%$.Vegetation of this study area is mainly of dry deciduous type dominated by Shorea robusta along with this area is very rich in cultivation of different plants. The river Falgu, Morhar, Sorhar, and a large number of temporary and permanent lentic water bodies and wetlands are present in the study area, that are the main habitat for large number of amphibian species as well many different species also. Cultivated land, Forest, Grasslands and is situated around the study sites. The study area (Figures 1-3) of present study is the Gaya district of Bihar province. We carried out the present study between March 17 February 18 which included a consecutive pre-monsoon, monsoon and post-monsoon periods. We selected three study sites of this district from the perspective of contrasting habitat characteristics that differ in amphibian species and their habitat preference also.

1. SITE-1: Ramsagar pond $\left(24.7735^{\circ} \mathrm{N}\right.$ and $\left.85.0320^{\circ} \mathrm{E}\right)$ was a large permanent artificial water body occupying $821.5 \mathrm{~m}^{2}$ area with a mean depth of $2 \mathrm{~m}$. Both floating and submerged aquatic weeds were noted in this pond. Because of Hindu rituals on the bank of this pond, this become very important for amphibian species. This pond was in the vicinity of dense human habitation and in the heart of Gaya city. Besides this pond, few small 
temporary water bodies, around this pond were also included for the sampling and identification of amphibian species of this area all 10 species of amphibians recorded from this area.

2. SITE-2: Daboor village pond $\left(24.8112^{\circ} \mathrm{N}\right.$ and $\left.84.7259^{\circ} \mathrm{E}\right)$ was selected as site-II covering an area of 5 acre with catchment area 20 acre. This pond is dominated by large amount of planktonic diversity act as food for amphibians. This site or study is very rich in amphibian diversity have large catchment area about that is surrounded by thick matty grasslands as well the agricultural fields provide suitable habitat for various species of amphibians and all the 9 species of amphibian recorded from here. It has about 15-20 temporary water bodies associated with it that provide thick vegetation around it that holds a great variety amphibian species. Main amphibian species are Euphlyctis cyanophlyctis, Hoplobatrachus tigerinus Duttaphrynus melanostictus, Sphaerotheca braviceps and Polypedates maculatus found abundantly here. The record of Polypedates maculatus (Common tree frog) was first from this sites and this district also.

3. SITE-3: Falgu river of Gaya district $\left(24.7528^{\circ} \mathrm{N}\right.$ and $84.1299^{\circ}$ E), covering an area of about 7-10 KM with catchment area about 40 acre. This river is surrounded by mountaneous region and cultivation land. It was a low lying area and in the monsoon, most of the area of this study site was inundated by temporary water and watery area become large during monsoon season. This site of study is also very rich in amphibian diversity and all the 9 amphibian species recorded from these areas. The main aphibian species was Euphlyctis cyanophlyctis, Hoplobatrachus tigerinus Duttaphrynus melanostictus, Sphaerotheca braviceps and Polypedates maculatus.

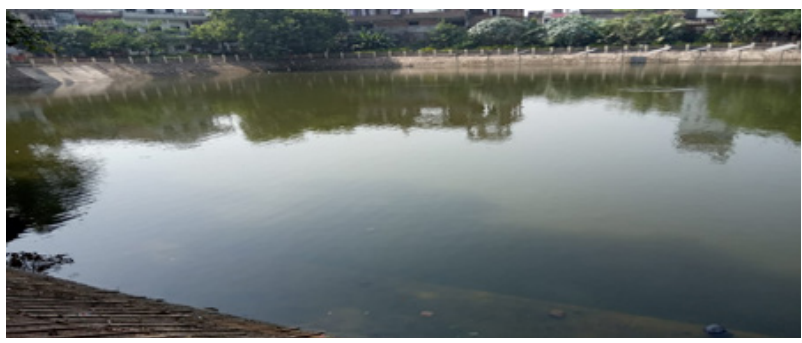

Figure I Ramsagar pond Gaya city.

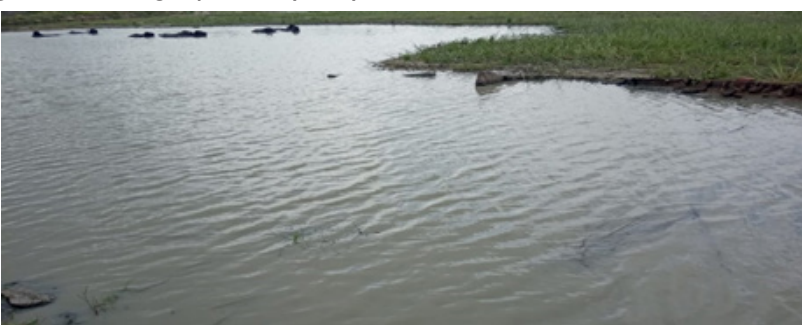

Figure 2 Daboor village pond.

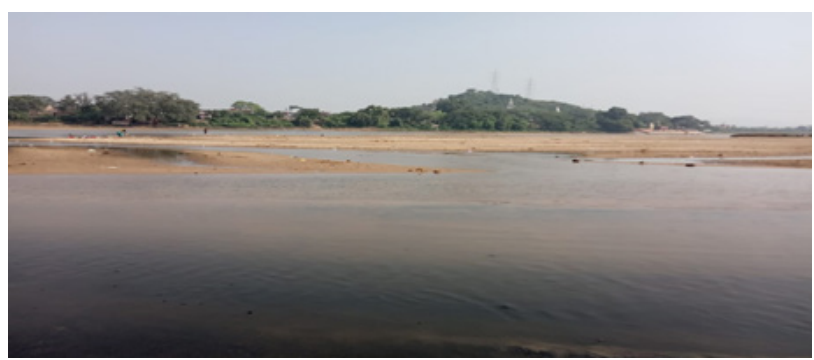

Figure 3 Falgu river Gaya.

\section{Materials and methods}

Present study was carried out through use of various sampling methods viz Visual encounter survey, Point count survey, Opportunistic search Road transect survey, Call count survey etc. The survey was performed bi-monthly in all possible habitats and microhabitats such as Leaf litter\& Bamboo grooves(LL\& BG), Tree hole (TH), Human residential area (HRA), Cultivated fields (CF), Patchy grasslands (PG), Forest and Hillly areas (FHA), Terrestrial land (TL) and water bodies (WB). During whole year. The timing of the survey is in between 5.30 am to 8.00 am in early morning and $7.00 \mathrm{pm}$ to $11.00 \mathrm{pm}$ in night. Anuran amphibian species were recorded by direct sighting method and also by recording the calls from the concerned species. Specimens were photographed at the site by Nikon camera D 7000 and lens $60 \mathrm{~mm}$ micro for further identification and documentation purpose. We calculated Shannon-Wiener diversity index, Pielou's evenness index, Margalef's richness index and Simpson's dominance index using D index software version 4.0. Photographs of the different species and their microhabitats were taken with a digital camera. Geographic position of study sites were also recorded by using a GPS mobile software. Coordinates were recorded as latitude and longitude in degrees.

The identification of amphibian specimens photographed done by using various identification keys and publications available such as Dubois, ${ }^{14}$ Bossuyt et al., ${ }^{15}$ Dutta et al. ${ }^{16}$ Chanda, ${ }^{17}$ Daniels, ${ }^{18}$ Das, ${ }^{19}$ Ahmed et al., ${ }^{20}$ Kabir et al., ${ }^{21}$ and Frost. ${ }^{22}$ Also some identification was confirmed by consulting Batrachologists. Nomenclature of Amphibians in this paper followed Frost. ${ }^{22}$ Four categories were used to express the relative abundance of different species. ${ }^{23}$ These are: Very Common (VC): species with 76-100 percent chance of being encountered when it is most active in its habitats; Common (C): species with 51-75 percent chance of being encountered; Uncommon (UC): species with 26-50 percent chance of being encountered and; Rare (R): species with 25 percent or less chance of being encountered.

\section{Result and discussion}

A total of 10 amphibians species of only of order Anura belonging to 4 families and 7 genera were recorded from the area around Ramsgar pond (site-1), 8 Anuran amphibians belonging to 4 families and 6 genera from the area around the Daboor village pond (site-2) and 9 Anuran amphibian species belonging to 4 families and 7 genera recorded from the area around Falgu river (site-3) of Gaya India. Many species of anuran amphibians are found to spend a good part of their life hiding, either in water under leaf litter, detritus, or on land under rocks or logs and even underground holes and termite mounds. ${ }^{24}$ Therefore with the increasing in microhabitats area and breeding sites area the diversity of anuran amphibian species increases greatly (Figure 1).

However, the amphibian diversity of different study sites of Gaya India region is moderate. During the survey we found only ten species of anuran amphibians under four families named, Bufonidae, Dicroglossidae, Microhylidae and Rhacophoridae. The amphibian species were represented by Duttaphrynus melanostictus, Duttaphrynus stomaticus, Hoplobatrachus tigerinus, Hoplobatrachus crassus, Sphaerotheca braviceps, Sphaerotheca rolandae, Euphlyctis cyanophlyctis, Fejervarya limnocharis, Uperedon systoma and Polypedates maculatus (Table 1). Among the recorded Anuran species the highest number of species recorded belonging to family Dicroglossidae and the minimum number of species recorded from the family Microhylidae. 

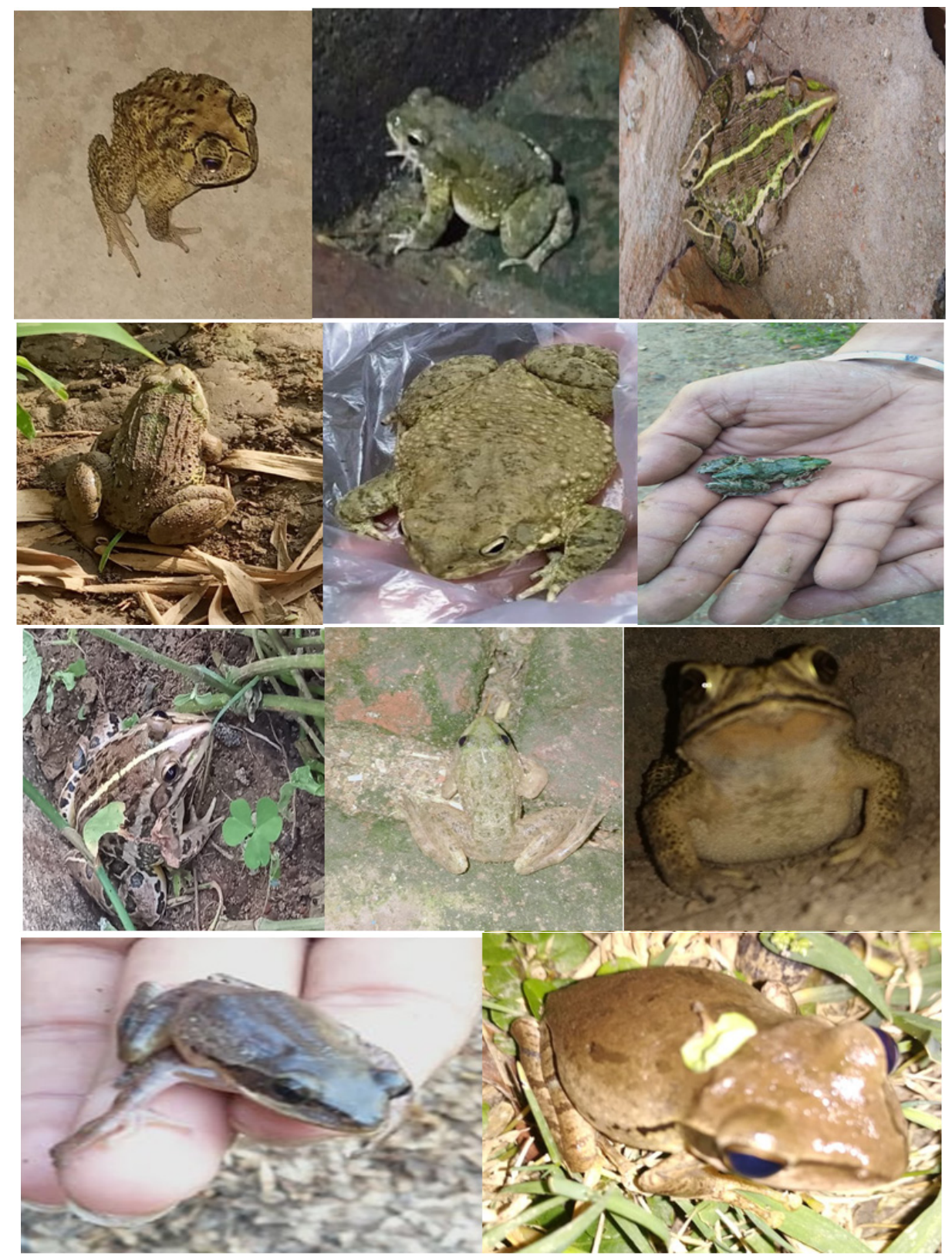

Figure 4 Different amphibian species found in Gaya, India.

Table I Amphibians (anuran) of gaya with their habitat preference, occurance, abundance and iucn status

\begin{tabular}{|c|c|c|c|c|c|c|}
\hline Family & Species & Common name & Habitat preference & Occurance & Abundance & IUCN status \\
\hline Bufonidae & $\begin{array}{l}\text { Duttaphrynus } \\
\text { melnostictus } \\
\text { (Schneider, 1799) }\end{array}$ & Common Asian toad & HRA, FHA,TL & I,II, III & C & LC \\
\hline Bufonidae & $\begin{array}{l}\text { Duttaphrynus } \\
\text { stomaticus } \\
\text { (Lutken, I864) }\end{array}$ & Marbled toad & TL, HRA, LL\&BG & I, II III & VC & LC \\
\hline Dicroglossidae & $\begin{array}{l}\text { Hoplobatrachus } \\
\text { tigerinus } \\
\text { (Daudin,1803) }\end{array}$ & Indian bullfrog & WB, TL, CF, FHA, PG & I, II, III & VC & LC \\
\hline Dicroglossidae & $\begin{array}{l}\text { Hoplobatrachus } \\
\text { crassus } \\
\text { (Hoffman, 1932) }\end{array}$ & Dicroglossidae Jerdon's bullfrog & WB, TL, CF, FHA, PG & I, II, III & $\mathrm{C}$ & LC \\
\hline
\end{tabular}


Table Continued...

\begin{tabular}{|c|c|c|c|c|c|c|}
\hline Family & Species & Common name & Habitat preference & Occurance & Abundance & IUCN status \\
\hline Dicroglossidae & $\begin{array}{l}\text { Sphaerotheca } \\
\text { braviceps } \\
\text { (Schneider, I799) }\end{array}$ & Indian burrowing frog & FHA, PG, TL & I,II, III & UC & LC \\
\hline Dicroglossidae & $\begin{array}{l}\text { Sphaerotheca } \\
\text { rolandae (Dubois, } \\
\text { 1983) }\end{array}$ & Roland's burrowing frog & FHA, PG, TL & I,III & $\mathrm{R}$ & \\
\hline Dicroglossidae & $\begin{array}{l}\text { Euphlyctis } \\
\text { cyanophlyctis } \\
\text { (Schneider, I799) }\end{array}$ & Skittering frog & WB, CF & I,II,III & VC & LC \\
\hline Dicroglossidae & $\begin{array}{l}\text { Frejerverya } \\
\text { limnocharis } \\
\text { (Gravenhorst, 1829) }\end{array}$ & Asias grass frog & WB, CF & I,II,III & UC & LC \\
\hline Microhylidae & $\begin{array}{l}\text { Uperedon systoma } \\
\text { (Schneider, I799) }\end{array}$ & Marbled balloon frog & FHA, Near WB & I & $\mathrm{R}$ & LC \\
\hline Rhacophoridae & $\begin{array}{l}\text { Polypedates } \\
\text { maculatus } \\
(\text { J.EGray, I830) }\end{array}$ & Common tree frog & HRA, TL, TH, FHA & I,III, III & C & LC \\
\hline
\end{tabular}

During our survey, family Dicroglossidae was found the most dominant family of frogs with 6 species followed by Bufonidae with 2 species and onlysingle species of Rhacophoridae and Microhylidae was found. It was observed that the Duttaphrynus stomaticus, Euphlyctis cyanophlyctis, Hoplobatrachus tigerinus and Polypedates maculatus species werefound in all the possible habitats. These four species had wide distribution and dominant throughout the Gaya district. While the Duttaphrynus melanostictus, Fejervarya limnocharis and Hoplobatrachus crassus were found mainly in agricultural fields and sub urban areas and recorded in less number. The food availability and habitat suitability was the prime factor for their occurrence in those fields. The Indian burrowing frog Sphaerotheca breviceps and Marbled balloon frog Uperedon systoma was found rare and found in and around Ramsagar pond of Gaya city only. The forest area and agriculture field provides the suitable habitat for the burrowing frog and Indian tree frog hence they preferred that areas and showed widespread distribution at all the sites of study. All the recorded species are least concern in the IUCN status. Leaf litter\& Bamboo grooves (LL\& BG), Tree hole (TH), Human residential area (HRA), Cultivated fields (CF), Patchy grasslands (PG), Forest and Hillly areas (FHA), Terrestrial land (TL) and water bodies (WB).

\section{Species diversity}

A total 10 anuran amphibian species under 4 families and 7 genus were recorded from three study areas (Table 1). Number of species in each protected area varied from 8 to 10 . Ramsagar pond supports the highest number of species (10) where Falgu river of Gaya city supports the lowest number of species (8). Family Dicroglossidae comprised $60 \%$ of the population ( 6 species), followed by Rhacophoridae $16 \%$ (1 species), Microhylidae 1\% (1 species), and Duttaphrynus $23 \%$ (2 species). All the three study areas had the highest number of frogs from the Family Dicroglossidae (5-6 species) and the lowest number from Microhylidae (1 species). Different diversity indices are calculated for all the study sites that reveals the idea about dominance, species diversity, composition. All the calculated values such as Shannon wiener diversity index, Simpsons dominance index, Margelafs richness index and Pielou's eveneness index for all sites (Table 3).
Table 2 Precent relative abundance of anuran species recorded during point counts survay in three study sites in Gaya India

\begin{tabular}{llll}
\hline Species & Site I & Site 2 & Site 3 \\
\hline Duttaphrynus melnostictus (Schneider, 1799) & 8.78 & 9.22 & 10.4 \\
Duttaphrynus stomaticus (Lutken, 1864) & 14.91 & 13.07 & 12.8 \\
Hoplobatrachus tigerinus (Daudin, I803) & 18.43 & 17.7 & 19.2 \\
Hoplobatrachus crassus (Hoffman, 1932) & 8.77 & 10 & 9.6 \\
Sphaerotheca braviceps (Schneider, I799) & 6.14 & 9.24 & 5.6 \\
Sphaerotheca rolandae (Dubois, I983) & 3.5 & 0 & 4 \\
Euphlyctis cyanophlyctis (Schneider, I799) & 20.17 & 20 & 16.8 \\
Frejerverya limnocharis (Gravenhorst, 1829) & 2.63 & 3.07 & 6.4 \\
Uperedon systoma (Schneider, I799) & 3.5 & 0 & 0 \\
Polypedates maculatus (J.EGray, 1830) & 13.17 & 17.7 & 15.2
\end{tabular}

Table 3 Calcualted diversity indices of all study sites of Gaya India

\begin{tabular}{llll}
\hline Diversity index & Site- I & Site - II & Site -III \\
\hline Shannon-Wiener Diversity Index (H') & 2.114 & 1.978 & 2.092 \\
Simpson's Dominance Index (DSIMP) & 0.136 & 0.147 & 0.136 \\
Margalef Richness Index (DMARG) & 1.9 & 1.438 & 1.657 \\
Pielou's Evenness Index (J') & 0.918 & $0.95 \mathrm{I}$ & 0.952
\end{tabular}

The Shannon-Wiener species diversity index (H'), mainly depends on comparative species abundances, was observed to be minimum at site-II (1.978) while comparatively high values were calculated from site-I (2.114) and site-III (2.092). These two sites contain lotic as well lentic water bodies were moist and high amphibian diversity were recorded in both the sites (site-II and site-III). Evenness is an important property of ecological communities and it is defines as the degree to which the abundances are equal among the species present in a sample or community. ${ }^{25}$ A community in which species 
composition is equally abundant has high evenness than a community in which the species differ widely in abundance has low evenness (Smith and Wilson, 1996). Pielou's evenness index $\left(\mathrm{J}^{0}\right)$ of was also very high for site-III(0.952) and site-II (0.951) while minimum at site-I (0.918). Simpson's dominance index $\left(\mathrm{D}_{\text {SIMP }}\right)$, which is also based on proportional abundance like H' revealed contrasting values to those of H'. The maximum was recorded from site-II (0.147) while comparatively much lower values at site-I and site-III(0.136).

Although both Shannon-Wiener and Simpson's indices consider the proportional abundance of species, $\mathrm{H}^{\prime}$ is more sensitive to rare species, where as $\mathrm{D}_{\text {SIMP }}$ put greater emphasis to common species. Therefore these indices point out occurrence of many diverse anuran species at site-II and site-III while only specially adapted species are confined to site-I. The use of diversity indices has increased due to the necessity of testing different methodologies to develop the ecological status. Richness is an indicator of the relative wealth of amphibian species in a community. The species richness (total number of species in each sample), and Margalef index, considering either the absolute number of individuals or the density, were calculated. ${ }^{26}$ The percentage variation was calculated as the ratio of Margalef index determined with the density matrix divided by the Margalef index determined with the absolute numbers matrix. Margalef's richness index $\left(\mathrm{D}_{\text {MARG }}\right)$, which considers both abundance and species numbers, also indicated that maximum values were associated with site-I (1.900) and site-III (1.657) while the minimum for the site-II (1.438). ${ }^{27}$

Amphibians are moisture loving creatures. Therefore the species diversity is expected to be high in moist places. This could be well established by the data that the amphibians preferred the habitat with high moisture and more microhabitat of the region that was indicated from site- I and site-III in the present study. However, perhaps to avoid competition some of the amphibian species of Gaya India have adapted large forest area as in evident from the data recorded from various sites Asian toad and Marbled Toad of family Duttaphrynus was found mainly near to the human habitations and in the agricultural fields. Hoplobatrahus and Polypedates species showed widespread distribution and were relatively more common than other species. They can be observed in majority of the habitats, including grasslands, water bodies, agricultural fields and human habitations. Euphlyctis cyanophlyctis showed restricted distribution and was found only in and around all the water bodies. During the study also we have recorded some direct and indirect threats to the Amphibian diversity of the study area such as extensive use of insecticides and weedicide by farmers to control the agricultural pest inhabiting the same localities, urbanization, road kills, habitat fragmentation, habitat loss and also modern agricultural practices.

\section{Conclusion}

The observations of this study showed the Anurans diversity and richness in and around the study area. This study may generated the base line data for the anurans diversity in Gaya district India. It was the preliminary study on the amphibian faunal diversity of this district of Bihar state but further study is also required for explore the diversity of anurans in the study area by addition of new amphibians species, habitat study, population estimation, and to find out the severity of the threats to diversity, and also to propose several conservation strategies in the study area.

\section{Acknowledgments}

None.

\section{Conflicts of interest}

None.

\section{Funding}

None.

\section{References}

1. Vitt LJ, Caldwell JP. Herpetology: An Introductory Biology of Amphibians and Reptile (4th edn.) Academic Press. San Diego. USA. 2014:776.

2. https://amphibiaweb.org/

3. Frost DR. Amphibian species of the World: an online reference. 2016.

4. Dinesh KP, Radhakrishnan C, Channakeshavamurthy BH, et al. Checklist of Amphibia of India, updated till April. 2020.

5. Venkateswarlu T, TSN Murthy. Fauna of Bihar State (India). Amphibia Indian Journal of Zoology. 1991;13(3):129-130.

6. Sarkar AK.The Amphibians of Chhotanagpur (Bihar) India. Rec zool Surv India. 1991;89(1-4):209-217.

7. Sarkar AK, Das S, Ray S. State fauna series 11: Fauna of Bihar (including Jharkhand). 2014:181-193

8. Abraham KS, PS Easa, SA Sabu Jahas, et al. Amphibian fauna of Wayanad, Kerala. Zoos' Print Journal. 2001;16(4):457-461.

9. Dahanukar N, A Padhye. Amphibian diversity and distribution in Tamhini, northern Western Ghats, India. Current Science. 2005;88(9):1496-1501.

10. Krishnamurthy SV. Amphibian assemblages in undisturbed and disturbed areas of Kudremukh National Park, central Western Ghats, India. Environmental Conservation. 2003;30(3):274-282.

11. Purushotham CB, K Dharmadhikari, R Vivek. A comparison of hill stream anuran diversity across two habitats in Kalakad-Mundanthurai Tiger Reserve: a pilot study. Frog Leg 2011;15: 2-9.

12. Meren Ao J, S Bordoloi, A Ohler. Amphibian fauna of Nagaland with nineteen new records from the state including five new records for India. Zoo's Print Journal. 2003;18(6): 1 1117-1125.

13. Ningombam B, S Bordolol. Amphibian fauna of Loktak Lake, Manipur, India with ten new records for the State. Zoo's Print Journal. 2007;2(5): $2688-2690$

14. Dubois A. Un nouveau complexe d'especes jumelles distinguees par le chant: les grenouilles du Nepal voisines de Rana limnocharis Boei (Amphibiens, Anoures). Comptes Rendus Academy of Science Paris (D). 281:1717-1720.

15. Bossyut F, Dubois A. A review of the frog genus Philautus Gistel, 1848 (Amphibia, Anura, Ranidae, Rhacophorinae). Zeylanica. 2001;6(1):1122.

16. Dutta SK, Manamendra-Arachchi K. The Amphibian Fauna of Sri Lanka. Wildlife Heritage Trust of Sri Lanka, Colombo. 1996:232.

17. Chanda SK. Handbook - Indian Amphibians. Zoological Survey of India, Calcutta. 2002; Viii:335.

18. Daniels RJR. Amphibians of Peninsular India. Universities Press (India) Private Ltd., Hyderabad. 2005.

19. Das A. Diversity and distribution of herpetofauna and evaluation of conservation status in BARAIL HERPETOFAUNA PROJECT, Final Report- March 2011. Conservation status in Barail Hill Range (including Barail Wildlife Sanctuary), Assam, Northeast India. Aaranyak. Guwahati. $2008.94 \mathrm{pp}$.

20. Ahmed MF, Das A, Dutta SK. Amphibians and Reptiles of Northeast India: A Photographic Guide. Aaranyak, Assam, India. 2009;163. 
21. Kabir SMH, Ahmed M, Ahmed ATA, et al. Encyclopedia of Flora and Fauna of Bangladesh, Vol. 25: Amphibians and Reptiles. Asiatic Society of Bangladesh, Dhaka. 2009;204.

22. Frost DR. Amphibian Species of the World: an online reference. 2020.

23. Khan MMH. Protected Areas of Bangladesh- A Guide to Wildlife. Nishorgo Program, Bangladesh Forest Department, Dhaka, Bangladesh. 2008.304.

24. Ray P. Systematic studies on the amphibian fauna of the district Dehradun Uttarpradesh, India. Memoirs of the Zoological Survey of India, Kolkata. 1999;18(3): 90
25. Molinari J. A calibrated index for the measurement of evenness. Oikos. 1989;56:319-323.

26. Gamito S. Caution is needed when applying Margalef diversity index. Ecological Indicators. 2010;10:550-551.

27. Dhande A, Khandare A. Occurrence of Kaloula taprobanica in Daryapur, Maharashtra. Frog leg. 2013;19:5-6. 